\title{
PROPOZYCJA WYCENY MARKI WG ZMODYFIKOWANEJ METODY BIEŻĄCEGO WYKORZYSTANIA NA PRZYKŁADZIE LODÓW AUGUSTO
}

\section{Wstęp}

We współczesnym, globalnym i nastawionym na wartości niematerialne świecie występowanie marki stało się całkowicie naturalne. Markę posiadają produkty, usługi, kolekcje odzieży oraz całe przedsiębiorstwa. Doszło nawet do sytuacji, w której Jezus Chrystus stał się „marką"1. Zjawisko, które z języka angielskiego zwane jest brandingiem, w dalszym ciągu stanowi dźwignię handlu i ważny składnik wartości przedsiębiorstw. Jednakże częściej obserwuje się kreowanie nowej marki niż próbę reaktywowania jej. W odniesieniu do marki będącej przedmiotem opracowania występuje druga $\mathrm{z}$ wymienionych sytuacji.

Autorzy przy okazji prac na zlecenie zewnętrznej firmy doradczej mieli okazję uczestniczyć w analizie potencjału i ocenie bieżącej wartości marki lodów Augusto, która jeszcze w latach 90. była najbardziej znaną marką polskiego producenta lodów ${ }^{2}$. Z uwagi na tajemnicę handlową autorzy nie ujawnili szczegółowych i dokładnych danych finansowych, przyjmując zarazem za główny cel pracy prezentację autorskiej koncepcji wyceny marki według zmodyfikowanej metody Interbrand. Jako hipotezę pracy przyjęto, że możliwa jest taka zmiana metody Interbrand, aby jej procedura stała się bardziej przystępna dla wykonawcy, a jednocześnie wynik zgodny z klasyczną postacią tejże metody. Jako przystępność należy rozumieć szerszą możliwość aplikacji metody bieżącego wykorzystania w wycenie marki.

We wspomnianym zleceniu wykorzystano tradycyjne ujęcie metody Interbrand, dlatego też weryfikacja hipotezy nastąpi poprzez porównanie uzyskanych wyników.

* Asystent, Katedra Inwestycji i Wyceny Przedsiębiorstw, Wydział Nauk Ekonomicznych i Zarządzania, US.

** Studentka, Koło Naukowe Marketingu, Wydział Nauk Ekonomicznych i Zarządzania, US.

${ }^{1}$ Taką tezę pośrednio stawia Tyler Wigg Stevenson w książce opublikowanej w 2007 r. pt. Brand Jesus, w której zarzuca organizacjom kościelnym, że oddały się konsumeryzmowi, poświęcając tradycyjne wartości.

${ }^{2}$ Porównywalny udział w rynku lodów miała wówczas marka Ekko, co zostanie wykazane w dalszej części opracowania. 


\section{Charakterystyka przedsiębiorstwa Kilargo i marki Augusto}

Przedsiębiorstwo Handlowo-Usługowe AUGUSTO-JAROCIN powstało w 1990 r. Dwa lata później, w wyniku podpisania umowy z Przedsiębiorstwem Produkcyjno-Handlowym AUGUSTO Sp. z o.o. w Kaliszu, powstała firma będąca zarówno producentem, jak i regionalnym dystrybutorem lodów. Dynamiczny rozwój rynku lodów spowodował, że w ciągu dekady Augusto stało się jedną z największych polskich firm produkujących lody (równorzędną pozycję posiadała wówczas spółka Ekko ze Szczecina).

Jak wynika z danych Głównego Urzędu Statystycznego, w roku 1990 produkcja lodów w Polsce wynosiła 20 tys. t rocznie, podczas gdy w 1999 r. było to już 80 tys. t rocznie. W trakcie tego okresu rekordowy był rok 1997, kiedy w kraju wyprodukowano 140 tys. t lodów. Kryzys rosyjski z 1998 r. znacząco zmniejszył eksport polskich firm, a dla Augusto stał się również przyczyną poważnych problemów finansowych, ponieważ zapotrzebowanie zgłaszane przez rosyjskich konsumentów stanowiło nawet 50\% produkcji Spółki. Tempo wzrostu popytu krajowego nie zrekompensowało jednak spadku eksportu po 1998 r., a ponadto rosła konkurencja ze strony koncernów międzynarodowych.

Głównymi markami lodów na polskim rynku w 2001 r. były: Algida (Unilever), Scholler, Koral z Nowego Sącza, Augusto z Kalisza, Zielona Budka z Warszawy, Nordis, Ekko oraz Ice Mastry. Strukturę sprzedaży w latach 1998 oraz 2001 prezentują poniższe wykresy. Można zaobserwować, że w obu okresach najczęściej kupowane były lody marki Algida należącej do koncernu Unilever. Udział lodów marki Augusto pod koniec lat 90. był w miarę stabilny i wynosił $9 \%$, podobnie jak marki Ekko.

W 2001 r. producenci ci poinformowali o fuzji i stworzeniu nowej spółki Nasze Lody. Ówczesne pierwsze komentarze analityków dotyczące tej inicjatywy były mocno wyważone. Wskazywano, że ,problemem może się okazać reorganizacja sieci dystrybucyjnej, ponieważ dotychczas każda z firm miała swoich hurtowników i swoje lodówki w sklepach. Specjaliści zastanawiali się jednak, jak te lodówki podzielić, z których zrezygnować"3. Rozwiązanie wszystkich kwestii spornych miało zostać rozłożone w czasie, dlatego też przyjęto, że opracowanie długoterminowej strategii działania potrwa około roku, tj. do 2002 r. Nic jednak z tych planów nie wyszło, ponieważ obie firmy złożyły wnioski o ogłoszenie upadłości. Od 16 lutego 2004 r. lody pod marką Augusto wytwarza firma Kilargo, która dokonała zakupu Augusto Kalisz od syndyka za kwotę 3,2 mln USD ${ }^{4}$.

\footnotetext{
${ }^{3}$ E. Wesołowska, Duże lody, „Businessman”, styczeń 2001, s. 57.

${ }^{4}$ Informacja pochodzi z bazy DealWatch prowadzonej przez serwis Euromonitor.
} 

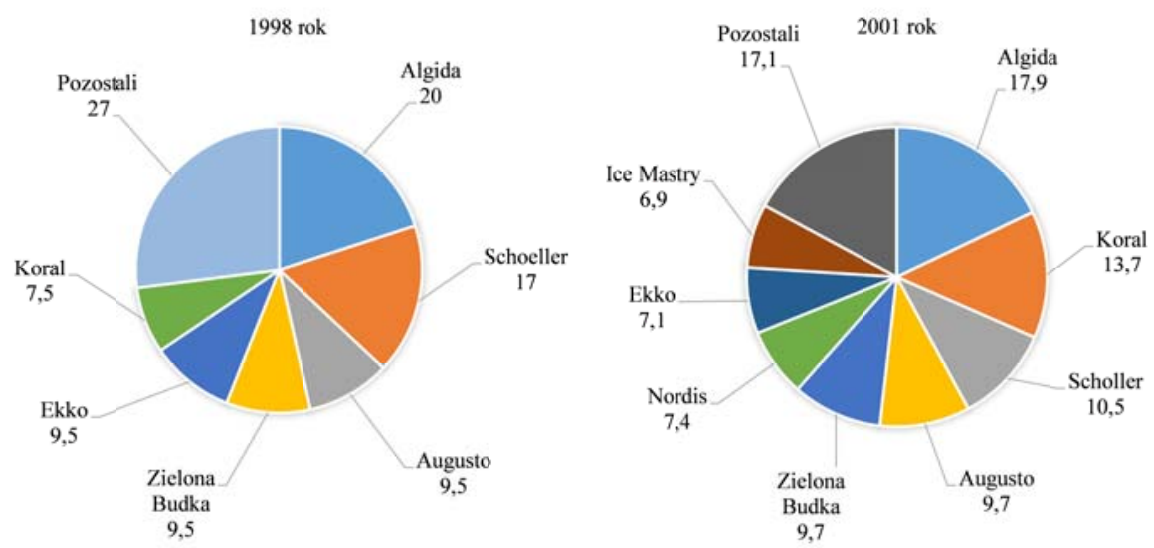

Rysunek 1. Udziały poszczególnych producentów w polskim rynku lodów w latach 1998 i 2001 (w \%)

Źródło: opracowanie własne na podstawie: Duże zdobywaja rynek, Rzeczpospolita z dnia 28 marca 1999, http://www.poradnikhandlowca.com.pl/bezcms/archiwum/online02/02/w\&t/ rap10.html [dostęp w dniu 11.05.2013].

Po okresie kilku lat Kilargo stało się jednym z większych producentów lodów w Europie Środkowo-Wschodniej. Produkcja prowadzona jest w dwóch fabrykach: w Chechle Pierwszym oraz w Kaliszu. Łączna zdolność produkcyjna fabryk sięga ok. 300 t lodów na dobę. Firma wyspecjalizowała się w produkcji wyrobów na zamówienie sieci handlowych, oznaczonych markami własnymi (tzw. private labels), ze sprzedaży których osiąga większość przychodów. Do klientów Kilargo należą m.in. LiG36dl, Biedronka, Tesco, Polomarket, Kaufland, Żabka, Iglotex, Penny, Intermarche, Metro, Auchan - ze swymi oddziałami w Polsce i za granicą.
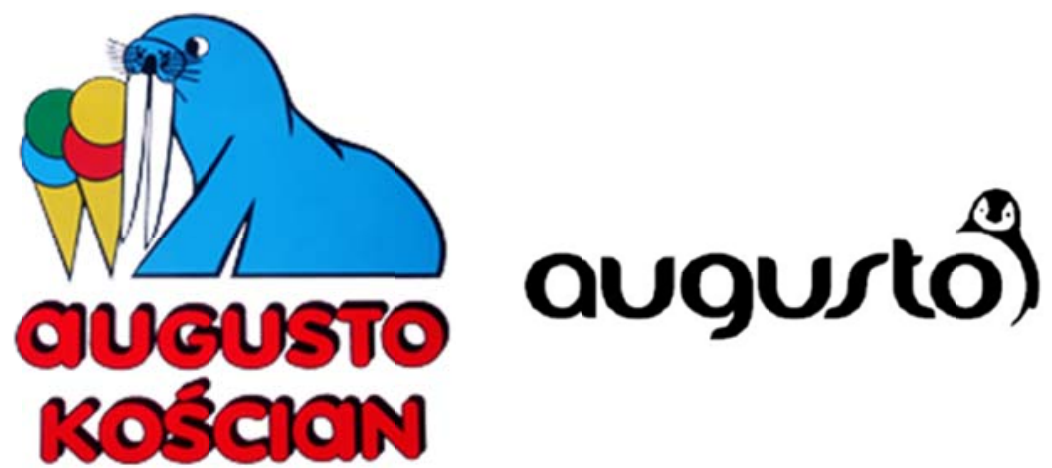

Rysunek 2. Logo marki Augusto w okresie ,przed upadłością” oraz obecnie Źródło: Materiały dostarczone przez Kilargo Sp. z o.o. w ramach prac nad ankietą. 
Obecnie w portfolio firmy znajdują się także produkty firmowane logiem Augusto, tj. Pinoccio, Gucio, Corner, Gulliver, Alizee oraz Joy i Bambo. Należy jednak zauważyć, iż aktualne logo Augusto jest diametralnie różne od poprzedniego, natomiast w świadomości starszych konsumentów marka ta wciąż jest rozpoznawalna. W celu określenia skali tej rozpoznawalności autorzy przeprowadzili badania ankietowe.

\section{Rozpoznawalność marki Augusto - wyniki badań ankietowych}

Badanie rozpoznawalności marki zostało przeprowadzone w okresie od 15 do 26 kwietnia wśród niesprecyzowanej bliżej grupy docelowej. Materiał statystyczny został zebrany za pomoca specjalnie opracowanej ankiety internetowej na stronie ankietka.pl stworzonej przez Koła Naukowe Wydziału Nauk Ekonomicznych i Zarządzania Uniwersytetu Szczecińskiego, która była wypełniana przez respondentów drogą elektroniczną ${ }^{5}$. Ankieta zawierała 15 pytań odnośnie do marki Augusto.

Dobór respondentów przeprowadzony był na zasadzie łatwości dostępu. Ankiety przyjęte do analizy były udostępniane przez stronę dydaktyczną prowadzoną przez Katedrę Inwestycji i Wyceny Przedsiębiorstw i portale społecznościowe. Ostatecznie do obliczeń i analizy przyjęto 297 ankiet prawidłowo wypełnionych. Średnia wieku osób ankietowanych to 29 lat. Najmłodszym uczestnikiem badania był trzynastolatek, a najstarszym mężczyzna w wieku 85 lat. Wśród badanych było 187 kobiet i 110 mężczyzn, gdzie 111 osób miało wykształcenie wyższe, 86 zawodowe, 85 średnie, a reszta gimnazjalne i podstawowe. Grupa ankietowanych była zbadana również pod względem statusu zawodowego. Większość wypełniających ankiety stanowili uczniowie lub studenci (37\%), na drugim miejscu znalazły się osoby pracujące (41\%), a dalej osoby uczące się i pracujące jednocześnie (18\%), natomiast reszta to bezrobotni, renciści i przedsiębiorcy (4\%).

Ankietowanym zostało zadane pytanie o ulubione smaki lodów. Wymienione rodzaje (śmietankowe, waniliowe, truskawkowe, czekoladowe, orzechowe, wiśniowe, owoce leśne, kawowe, w tym tiramisu, czarna porzeczka, wieloowocowe) musieli ustawić malejąco. Okazało się, że badani ustawili preferowane smaki lodów w sposób zbliżony do wyników analiz przeprowadzonych w 2012 r. przez serwis Euromonitor ${ }^{6}$.

\footnotetext{
${ }^{5}$ Ankieta była dostępna pod adresem https: //www.ankietka.pl/ankieta/111786/ocena-sily-iznajomosci-marki-lodow-augusto-kola-naukowe.html (dostęp 14.10.2013).

${ }^{6}$ Passport. Ice Cream in Poland, „Euromonitor International”, January 2013, s. 6. Różnica pomiędzy przeprowadzonym badaniem a podawanymi wynikami sprowadzała się do umiejscowienia lodów o smaku czekoladowym wyżej od smaku truskawkowego.
} 
Przeprowadzono również ocenę preferowanej formy lub miejsca zakupu lodów. Ankietowani wskazywali, że przeważnie wybierają lody impulsowe (228) ${ }^{7}$. Kolejny wybór respondentów to lody familijne $(180)^{8}$, następnie lody z automatów (120), a na samym końcu desery lodowe kupowane w restauracjach (87).

Kolejne pytania stanowiły część zasadniczą ankiety i dotyczyły marki Augusto. Spośród 297 ankietowanych znajomość marki potwierdziło 171 osób, dlatego też tylko ta grupa odpowiadała na bardziej szczegółowe pytania.

Tabela 1. Wybrane wyniki zrealizowanego badania ankietowego w części dotyczącej marki Augusto

\begin{tabular}{|c|c|c|c|c|c|c|}
\hline Zagadnienie & \multicolumn{5}{|c|}{ Warianty odpowiedzi } \\
\hline $\begin{array}{c}\text { Znajomość } \\
\text { marki }\end{array}$ & \multicolumn{3}{|c|}{ tak (171) } & \multicolumn{3}{c|}{ nie (126) } \\
\hline $\begin{array}{c}\text { Ocena pozycji } \\
\text { marki }\end{array}$ & $\begin{array}{c}\text { lider rynku } \\
(0)\end{array}$ & silna (16) & $\begin{array}{c}\text { umiarkowana } \\
(80)\end{array}$ & słaba (72) & $\begin{array}{c}\text { marka nie } \\
\text { odgrywa roli } \\
(3)\end{array}$ \\
\hline $\begin{array}{c}\text { Częstotliwość } \\
\text { zakupu }\end{array}$ & nigdy (29) & \multicolumn{7}{|c|}{ rzadko (82) } & $\begin{array}{c}\text { czasami- } \\
\text { przynajmniej raz } \\
\text { na kwartal (46) }\end{array}$ & $\begin{array}{c}\text { często- przy- } \\
\text { najmniej raz } \\
\text { w miesiącu (14) }\end{array}$ \\
\hline $\begin{array}{c}\text { Jakość } \\
\text { produktu }\end{array}$ & $\begin{array}{c}\text { bardzo } \\
\text { wysoka (1) }\end{array}$ & wysoka (3) & średnia (95) & niska (58) & $\begin{array}{c}\text { bardzo niska } \\
\text { (14) }\end{array}$ \\
\hline
\end{tabular}

Źródło: opracowanie własne na podstawie przeprowadzonych badań ankietowych.

Ankietowani pytani o intensywność zakupu lodów marki Augusto w największej liczbie wskazali odpowiedź „rzadko” (82), co świadczy o umiarkowanej popularności tych produktów wśród konsumentów. Potwierdzają to sami ankietowani, którzy w 89\% odpowiedzieli, że pozycja marki Augusto jest słaba lub umiarkowana. Warto jednak zwrócić uwagę na to, że nikt nie uplasował tejże marki na pozycji lidera. Analizie poddano również jakość lodów Augusto, w ramach której 95 osób oceniło ją jako średnią, natomiast 72 uważają, że jest wysoka i bardzo wysoka.

Powyższy duży odsetek znajomości marki Augusto (57\%) nie znajduje jednak potwierdzenia $\mathrm{w}$ innych badaniach ankietowych oraz raportach rynkowych. Przykładowo, w analizie zachowania konsumentów na rynku lodów w województwie lubuskim, zrealizowanej w okresie od maja do sierpnia 2012 r., żaden z 356 badanych nie wskazał produktów oznaczonych marką Augusto jako

\footnotetext{
${ }^{7}$ Autorzy za lody impulsowe uważają rożki, na patyku, w wafelku, małe kubeczki.

${ }^{8}$ Do kategorii lodów familijnych autorzy zaliczyli lody w dużych opakowaniach o pojemności pow. $500 \mathrm{ml}$.
} 
najczęściej kupowanych ${ }^{9}$. Podobnie w analizach serwisu Euromonitor, mimo że marka Augusto jest wyróżniona, to brak jest jakichkolwiek statystyk ${ }^{10}$.

Wśród pytań, które zadano respondentom, znalazły się również te dotyczące oceny siły marki Augusto według parametrów BrandAsset Valuator ${ }^{11}$. Respondenci, wykorzystując skalę od 0 do 100, musieli ocenić:

- odmienność marki, tzn. wybierali, w jakim stopniu marka się wyróżnia (poziom 0 - marka w ogóle się nie wyróżnia, poziom 100 - bardzo się wyróżnia),

- zapotrzebowanie na markę, a więc czy dostrzegają potrzebę istnienia tej marki na rynku (poziom 0 - nie jest potrzebna, poziom 100 - jest potrzebna),

- szacunek do marki, czyli czy firma jest dobrze postrzegana (poziom 0 - nie jest szanowana, poziom 100 - jest bardzo szanowana),

- wiedzę na temat marki, co jest tożsame ze znajomością firmy (poziom 0 - marka jest nie znana, poziom 100 - jest bardzo znana)

Koncepcja BAV zakłada, że występuje pięć etapów rozwoju marki: start, niewykorzystany potencjał, pozycja lidera, utrata potencjału i rozpad. Z przeprowadzonego badania wynika, że marka Augusto cechuje się niewykorzystanym potencjałem. Jest to sytuacja charakterystyczna dla marek, które wyróżniają się wyższym potencjałem wzrostu (odmienność i zapotrzebowanie) od aktualnej siły (szacunek i wiedza). W przypadku tej marki największe wartości charakterystyk otrzymano dla „zapotrzebowania na markę” $(53,22)$ oraz „odmienności marki” (41,83). W odniesieniu do pozostałych czynników, tj. „szacunku” i „wiedzy”, uzyskano zbliżony wynik - ok. 37 punktów. Wyniki analizy siły marki Augusto zostaną wykorzystane w dalszej części opracowania jako element modelu wyceny jej wartości.

\section{Zarys metod wyceny marki}

Literatura przedmiotu wskazuje na istnienie wielu odmiennych metod wyceny marki, a dodatkowo brak jest powszechnej zgody co do istnienia jednej mającej największą efektywność lub wiarygodność. Stan ten wynika przede wszystkim stąd, że składniki niematerialne aktywów mają unikatowy charakter i nie są przedmiotem powszechnie zawieranych transakcji rynkowych. W sytuacji, gdy kontynuacja działalności przedsiębiorstwa nie jest

${ }^{9}$ S. Urban, M. Michałowska, Zachowania konsumentów na rynku lodów w województwie lubuskim, „Chłodnictwo” 2012, t. XLVII, nr 11, s. 48.

${ }^{10}$ Passport. Ice Caream...

${ }^{11}$ A. Paszkiewicz, Ocena sity marki na rynku na podstawie Brand Asset Valuator, „Prace i Materiały Wydziału Zarządzania Uniwersytetu Gdańskiego. Przedsiębiorstwo w Warunkach Kryzysu” 2009, nr 3/2, s. 481. 
zagrożona $^{12}$ na wartość marki składają się (1) wartość ochrony, którą jest ona objęta (co wyrażają nakłady poniesione na rejestrację i zastrzeżenie praw do znaku towarowego) oraz (2) siła marki, która reprezentuje skuteczność zarządzania marketingowego. Metody wyceny znaku towarowego można podzielić na trzy podstawowe grupy:

1) podejście kosztowe,

2) podejście porównawcze,

3) podejście dochodowe.

Podejście kosztowe przewiduje konieczność oszacowania wysokości nakładów, które przedsiębiorca powinien ponieść, aby mógł realizować w przyszłości takie same korzyści ekonomiczne, jakich dostarcza obecnie konkretna marka. Przykładowo, P. Stobart ${ }^{13}$ w podejściu kosztowym wyróżnia: metodę kosztów odtworzenia (kosztów reprodukcji) oraz metodę kosztów zastąpienia. Inaczej do podejścia kosztowego podchodzi M. Birkin ${ }^{14}$, według którego wartość marki równa jest sumie kosztów poniesionych w przyszłości na wykreowanie danej marki (metoda kosztu historycznego). Jeszcze jedno ujęcie podejścia kosztowego będącego szczególnie popularne w literaturze anglojęzycznej podaje D. Zarzecki ${ }^{15}$, gdzie zwraca się uwagę na metodę kosztu duplikacji.

Podejście porównawcze (zwane także rynkowym) polega na wykorzystaniu informacji o faktycznie zrealizowanych cenach $\mathrm{w}$ transakcjach kupna-sprzedaży podobnych aktywów. Stosowanie tej metody oparte jest na zasadzie analogii, tzn. wykorzystuje przesłankę, iż marki o tej samej sile powinny mieć zbliżoną wartość ${ }^{16}$. Wycena według podejścia porównawczego zakłada jednocześnie istnienie silnego związku pomiędzy ceną transakcyjną, która jest efektem porozumienia kupującego i sprzedającego, a wartością godziwą lub ekonomiczną marki. Zastosowanie podejścia porównawczego do oszacowania wartości marki, podobnie jak ma to miejsce w przypadku wyceny przedsiębiorstw, wymaga istnienia aktywnego rynku obrotu oraz dostępności do informacji o transakcjach. Obecnie w warunkach polskich podejście to ma najmniejszą wartość użyteczną.

${ }^{12}$ Szczególnym przypadkiem jest bowiem sytuacja, gdy przedsiębiorstwo zostaje postawione w stan upadłości, a wartość marki koncentruje się przede wszystkim na prawie do jej ochrony.

${ }^{13}$ P. Stobart, Alternative methods of brand valuations, [w:] J. Murphy (ed.), Brand Valuation, Business Books Limited, London-Sydney-Auckland-Johannesburg 1991, s. 26-27.

${ }^{14}$ M. Birkin, Valuation of trademarks and brand names, [w:] J. Murphy (ed.), Brand Valuation, Business Books Limited, London 1985, s. 35.

${ }^{15}$ D. Zarzecki, Wybrane problemy wyceny wartości niematerialnych $i$ prawnych, Seria SWSPiZ w Łodzi, Przedsiębiorczość i Zarządzanie, t. VII, z. 1B, Efektywność źródtem bogactwa narodów, Łódź-Wrocław 2006, s. 448.

${ }^{16}$ Wysokość nakładów niezbędnych do uzyskania prawa ochronnego ma marginalne znaczenie dla różnicy w wartości marek. 
Podejście dochodowe zwane jest również grupą metod przychodowych lub ogólnie metodami ekonomicznymi. Przyjmując ogólną zasadę metod dochodowych, marka jest to aktywo generujące przychody ${ }^{17}$. W metodach dochodowych wykorzystuje się informacje o korzyściach ekonomicznych, które generowane są $\mathrm{z}$ tytułu posiadania marki ${ }^{18}$. Metody zostały oparte na bazie tego, jakie są oczekiwania każdego właściciela marki, czyli zwrotów z jej posiadania. Wśród metod dochodowych występuje metoda, która nosi nazwę procedury bieżącego wykorzystania (Existing Use Method).

Punktem wyjścia jest tu obecna pozycja i sposób zarządzania marką. Zgodnie z założeniami, nie bierze się pod uwagę wszelkich radykalnych zmian, które mogłyby nastąpić w przyszłości, takich jak: ewentualne poszerzenie marki, licencjonowanie czy też zmiany $\mathrm{w}$ strategii promocji. Metoda Interbrand jest zmodyfikowaną procedurą przepływów gotówkowych, która opiera się na idei, według której marka może być wyceniana $\mathrm{z}$ zastosowaniem stopy dyskontowej lub mnożnika odpowiednio do przewidywanych lub istniejących zysków związanych z marką. W zależności od tego, czy do wyceny wykorzysta się dane prognozowane lub też wielkości historyczne, w celu określenia zysków związanych z produktem opatrzonym daną marką najczęściej stosuje się 5-letnią prognozę bądź wykorzystuje się średnią ważoną z ostatnich 3 lat ${ }^{19}$. Szczegółowo procedura wyceny metodą Interbrand została opisana m.in. przez G. Urbanka oraz S. Wronę ${ }^{20}$, dlatego też $\mathrm{w}$ dalszej części opracowania zaprezentowano jedynie obliczenia.

\section{Oszacowanie wartości marki lodów Augusto zmodyfikowaną metodą Interbrand}

Wartość oszacowana metodą Interbrand jest wypadkową dochodowości marki oraz mnożnika, którego poziom zależy od siły marki. W klasycznej koncepcji siłę marki określa się za pomocą siedmiu czynników, tj. przywództwo, stabilność, rynek, umiędzynarodowienie, trend, poparcie i ochrona. Każdemu z parametrów przydziela się odpowiednią liczbę punktów, natomiast suma

${ }^{17}$ S. Wrona, pomiaru wartości marki, [w:] J. Mońka, D. Sołtys (red.), Wyznaczniki rozwoju przedsiębiorstwa - wartość, koszty, płynność, Wydawnictwo Akademii Ekonomicznej im. Oskara Langego, Wrocław 2001, s. 181.

${ }_{18}$ P. Polański, Metody pomiaru wartości marki, [w:] B. Dobiegała-Korona, A. Herman (red.), Współczesne źródta wartości przedsiębiorstwa, Difin, Warszawa 2006, s. 427.

${ }^{19}$ A. Paszkiewicz, Dochodowa metoda wyceny marki na przyktadzie procedury Interbrand, Prace i Materiały Wydziału Zarządzania Uniwersytetu Gdańskiego, nr 4, Gdańsk 2007, s. 60.

${ }^{20}$ G. Urbanek, Wycena aktywów niematerialnych, PWE, Warszawa 2008; S. Wrona, Wybrane metody... 
wszystkich ocen nie może przekroczyć 100. W konsekwencji procedura ta wymaga, aby analityk posiadał szeroką wiedzę ekonomiczną, co de facto oznacza, że powinien być ekspertem w zakresie rynku, na którym występuje ta marka. Firma Interbrand zatrudnia specjalistów z różnych dziedzin, którzy na bieżąco analizują szereg zdarzeń gospodarczych i są niejako uprawnieni do oceny marki według wymienionych czynników. W odniesieniu do wyceny marki Augusto autorzy proponują zatem modyfikację metody Interbrand w aspekcie oceny jej siły i wykorzystania w tym celu wyników badań ankietowych oraz metody BAV. Oznacza to, że siłę marki oceniono na podstawie odmienności, potrzeby, szacunku i wiedzy, a ostateczny wskaźnik siły stanowi średnią. Przyjęto więc założenie, że cecha, jaką jest siła marki, może być określana na różne sposoby przy zachowaniu tej samej dziedziny wartości (od 0 do 100). Tym samym wzór na wartość marki Augusto będzie następujący:

$$
\text { wartość marki Augusto }=2,278 * 15,13=34,466 \mathrm{mln} z t
$$

Z uwagi na fakt, że dane o zyskowności lodów oznaczonych marką Augusto stanowią tajemnicę handlową firmy Kilargo, autorzy wskażą jedynie poziom średniej dochodowości z lat 2010-2012 bez szczegółowego rozbicia na lata. Dodatkowo dane zostaną zaokrąglone do mln zł i trzech miejsc po przecinku. Przeciętna zyskowność lodów marki Augusto wyniosła 2,278 mln zł.

We wprowadzeniu wskazano, iż celem opracowania jest przede wszystkim prezentacja autorskiej koncepcji połączenia metod BAV i Interbrand, a sam szacunek wartości stanowi tylko przykład jej zastosowania. Dlatego też w ocenie autorów powyższe zastrzeżenia odnośnie do danych przyjętych do obliczeń nie stoją w sprzeczności w stosunku do celu referatu.

Wartość mnożnika siły marki ustalona została na podstawie S-funkcji (funkcja S kształtna, sigmoidalna), a więc tak jak ma to miejsce w klasycznej metodzie Interbrand. Jak wynika z przeprowadzonych badań ankietowych, siła marki Augusto to 42,25 punktów. Przyjmując, że wartość mnożnika zawiera się w przedziale od $6,6(6)$ do $33,3(3)^{21}$, to przy tak ustalonej ocenie siły marki mnożnik wynosi 15,13 (jest to wartość S-funkcji dla $\mathrm{x}=42,25$ ). Podstawiając wartości do równania (1), dokonano wyceny marki Augusto.

wartość marki Augusto $=2,278 * 9,246=21,061 \mathrm{mln} \mathrm{zt}$

${ }^{21}$ Górny przedział mnożnika siły marki ustalono na podstawie opracowania A. Paszkiewicz, Dochodowa ..., s. 61. Reprezentuje on wolną od ryzyka stopę zwrotu wynoszącą 3\%. W odniesieniu do dolnej granicy przedziału (20) przyjęto poziom 15\%, który jest charakterystyczny dla ryzykownych inwestycji. 
Oszacowana wartość wynosi 21,061 mln zł, co na przykład w zestawieniu $\mathrm{z}$ rankingiem polskich marek jest wartością zbliżoną do tego jak oceniane są marki Zielona Budka (23 mln zł) oraz Grycan ( $25 \mathrm{mln}$ zł).

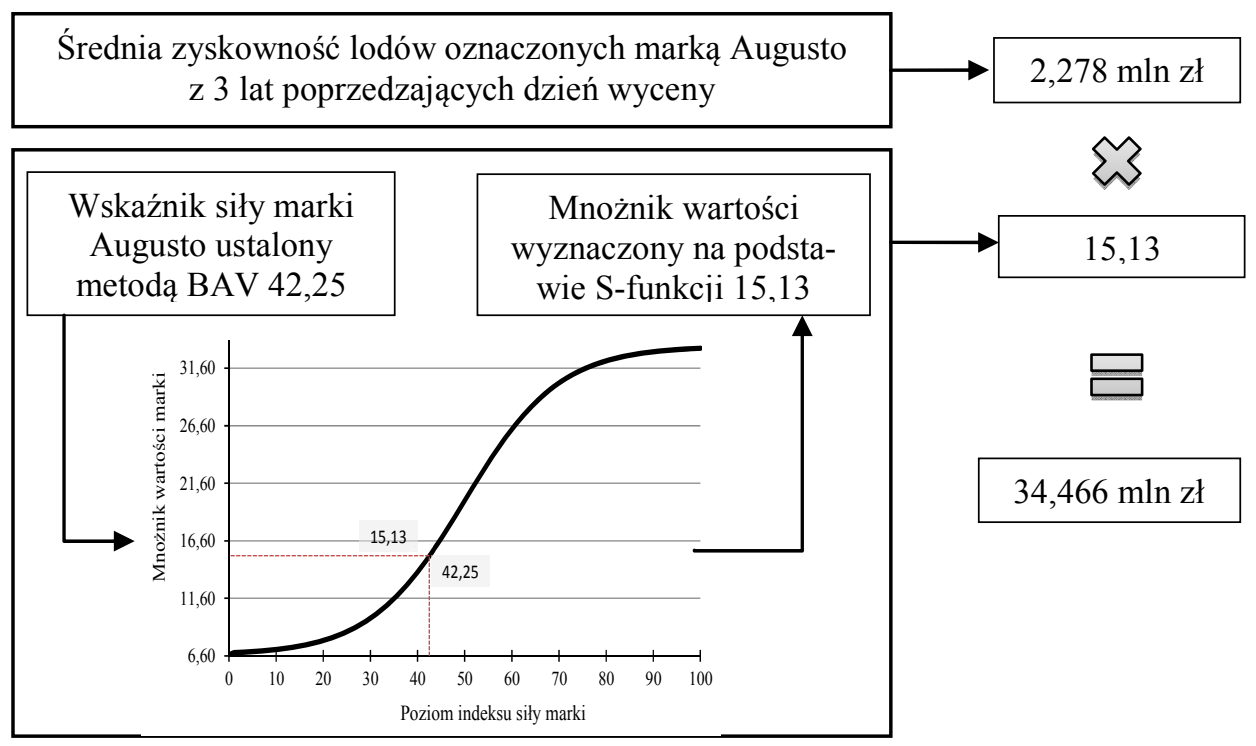

Rysunek 3. Ogólny schemat zastosowanej procedury wyceny marki lodów Augusto Źródło: opracowanie własne.

\section{Zakończenie}

W zaprezentowanym opracowaniu autorzy dokonali oszacowania wartości marki lodów Augusto z wykorzystaniem rozwiązań stosowanych przez firmę doradczą Interbrand według metody bieżącego wykorzystania, ale z jednoczesną modyfikacją tejże metody $\mathrm{w}$ kwestii pomiaru siły marki. Zaproponowana przez autorów modyfikacja metody Interbrand poprzez wprowadzenie czynników siły według podejścia BAV nie prowadzi do zmniejszenia jej wartości użytkowej, natomiast pozwala $\mathrm{w}$ inny sposób spojrzeć na siłę marki. W wyniku przeprowadzonego badania ankietowego autorzy potwierdzili relatywną łatwość analizy siły marki za pomocą czynników BAV, a ponadto uzyskany wynik potwierdza szacunek wartości, który otrzymano w wycenie dla klienta zewnętrznego.

Na potrzeby badania ankietowego przyjęto, że respondenci będą w stanie bardziej zrozumieć określenia: odmienność, potrzeba, szacunek i wiedza niż przywództwo, stabilność, rynek, umiędzynarodowienie, trend, poparcie i ochrona. Przeciętny konsument nie zastanawia się nad faktem, czy dana marka jest 
chronionym znakiem towarowym i chociaż jest to ważne zagadnienie, to nie stanowi dziś o sile marki na rynku. Dzięki tak przyjętym rozwiązaniu udało się ustalić, że marka Augusto ma niewykorzystany potencjał, co z punktu widzenia jej rozwoju stanowi istotną informację dla właścicieli.

\section{Literatura}

Birkin M., Valuation of trademarks and brand names, [w:] J. Murphy (ed.), Brand Valuation, Business Books Limited, London 1985.

Duże zdobywaja rynek, „Rzeczpospolita”, 28.03.1999.

Passport. Ice Cream in Poland, „Euromonitor International”, January 2013.

Paszkiewicz A., Dochodowa metoda wyceny marki na przykładzie procedury Interbrand, Prace i Materiały Wydziału Zarządzania Uniwersytetu Gdańskiego, nr 4, Gdańsk 2007.

Paszkiewicz A., Ocena sity marki na rynku na podstawie Brand Asset Valuator, „Prace i Materiały Wydziału Zarządzania Uniwersytetu Gdańskiego. Przedsiębiorstwo w Warunkach Kryzysu”, nr 3/2, Gdańsk 2009.

Polański P., Metody pomiaru wartości marki, [w:] B. Dobiegała-Korona, A. Herman (red.), Wspótczesne źródła wartości przedsiębiorstwa, Difin, Warszawa 2006.

Stobart P., Alternative methods of brand valuations, [w:] J. Murphy (ed.), Brand Valuation, Business Books Limited, London-Sydney-Auckland-Johannesburg 1991.

Urban S., Michałowska M., Zachowania konsumentów na rynku lodów w województwie lubuskim, „Chłodnictwo" 2012, t. XLVII, nr 11.

Urbanek G., Wycena aktywów niematerialnych, PWE, Warszawa 2008.

Wesołowska E., Duże lody, „Businessman”, styczeń 2001.

Wrona S., Wybrane metody pomiaru wartości marki, [w:] J. Mońka, D. Sołtys (red.), Wyznaczniki rozwoju przedsiębiorstwa - wartość, koszty, plynność, Wydawnictwo AE im. Oskara Langego, Wrocław 2001.

Zarzecki D., Wybrane problemy wyceny wartości niematerialnych i prawnych, Seria SWSPiZ w Łodzi, Przedsiębiorczość i Zarządzanie, t. VII, z. 1B, Efektywność źródlem bogactwa narodów, Łódź-Wrocław 2006.

https: //www.ankietka.pl/ankieta/111786/ocena-sily-i-znajomosci-marki-lodow-augusto-kolanaukowe.html

\section{Streszczenie}

Przedmiotem zainteresowania autorów opracowania jest marka lodów Augusto, której producentem jest firma Kilargo. Jeszcze w latach 90. lody Augusto posiadały $10 \%$ rynku i były najchętniej kupowanymi lodami polskiej produkcji, natomiast dziś marka ta nie występuje nawet w statystykach rynkowych. Wykorzystując metodę badań ankietowych zweryfikowano znajomość produktów oznaczonych logiem Augusto $(57 \%)$ oraz ustalono siłę tej marki wg czynników metody BrandAsset Valuator $(42,25)$. Za cel opracowania przyjęto prezentację autorskiej koncepcji wyceny marki wg zmodyfikowanej metody bieżącego wykorzystania stosowanej przez firmę Interbrand, gdzie do policzenia mnożnika siły marki zastosowano parametry z metody BAV. Możliwość praktycznego zastosowania koncepcji zweryfikowano na przykładzie marki Augusto, której oszacowana wartość wyniosła 34,466 mln zł. 


\section{Summary}

\section{A PROPOSITION MODIFIED METHOD OF BRAND VALUATION BASED ON THE CURRENT USE FOR EXAMPLE AUGUSTO - ICE CREAM BRAND}

The focus of the study's authors Augusto is a brand of ice cream, which is being produced by Kilargo. Even in the 90`s ice Augusto had 10\% of the market and are top sellers Polish ice cream production, and today the brand is not even in market statistics. Using the survey method was verified knowledge of products bearing the logo Augusto (57\%) and the strength of the brand established by factors methods BrandAsset Valuator $(42,25)$. The objective is to develop a presentation adopted original concept of brand valuation based on the current use of the modified method used by Interbrand, where the force multiplier to calculate the parameters used by the method of BAV. The possibility of practical application of the concept was verified by Augusto example, the estimated value was 34.466 million PLN. 